\section{Body position of dead honey bee workers could indicate the cause of death}

\author{
Hossam F. Abou-Shaara* \\ Department of Plant Protection, Faculty of Agriculture, Damanhour University, Damanhour, 22516, \\ Egypt
}

*Corresponding author, E-mail: hossam.farag@agr.dmu.edu.eg

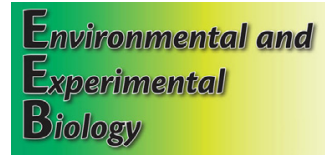

ISSN 2255-9582

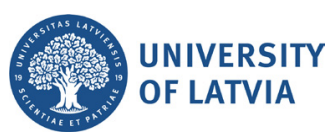

\begin{abstract}
The death of honey bees can happen due to various reasons. It is important to specify the cause of death, in order to recommend the correct treatment option. Dead bees have specific body positions (e.g. extended proboscis, separated wings, extended stingers), which can be described to help in the identification of the death cause. There are no previous evidence on links between body positions of dead bees and death cause. In this study, honey bee workers were exposed to various lethal conditions (low temperature, high temperature, starvation, suffocation, pesticide exposure, and food contamination). Then, the body positions of dead bees exposed to each lethal condition were described in detail. Differences in positions of antenna, proboscis, wings, legs, abdomens, and stingers were detected between dead bees exposed to the tested lethal conditions. These differences are discussed and further studies were then recommended. This study presents the potential use of baseline observations on relationships between the body position of dead bees to stress factors as a mean to predict the cause of death of honey bee workers.
\end{abstract}

Key words: Apis mellifera, mortality analysis, stress.

\section{Introduction}

The health of honey bees (Apis mellifera L., Hymenoptera: Apidae) is a major concern to the agricultural sector worldwide. It is well known that many plants depend on honey bees as pollinators (Morse, Calderone 2000; AbouShaara 2015a); hence the pollination services by honey bees are essential for agricultural production (e.g. Qaiser et al. 2013). There are many impacts on honey bees due to unsuitable environmental conditions and pesticide applications (Johnson 2015; Al-Ghamdi et al. 2016; Zhang 2018). One of the common examples of major loss of honey bees is the phenomenon of colony collapse disorder. This phenomenon causes a massive disappearance of bees from their colonies. A combination of many reasons has been proposed to be the cause of this phenomenon (Oldroyd 2007; Maini et al. 2010; Carreck 2014). Fortunately, there are many control options and solutions available for problems that affect bee health causing bee death. However, choice of the suitable option can made only after the correct diagnose of the cause of death.

Various abiotic and biotic factors can result in the death of honey bees. One of the major causes of death of honey bees is exposure to pesticides. Honey bees can be affected by pesticide through the contamination of food or water (Johnson 2015; Zhang 2018). Residues of systemic pesticides can be present in nectar and pollen of treated plants (Barker et al. 1980; Dively, Kamel 2012) and consequently affecting the survival and health of bees. Colonies may fail because of adverse weather conditions, particularly due to low temperature in winter (van Engelsdorp et al. 2008; Genersch et al. 2010; Nguyen et al. 2010; Spleen et al. 2013; Abou-Shaara 2017) or high temperature during summer (Abou-Shaara et al. 2013; Al-Ghamdi et al. 2016). Colony strength can also be significantly reduced by starvation (Brodschneider et al. 2010; Abou-Shaara 2017). Correct diagnosis of the cause of death can help protect colonies from significant bee losses. It was hypothesized that the cause of death of honey bees can be diagnosed based on the body position of dead bees. To test this hypothesis, honey bee workers were exposed to various lethal conditions (sub-freezing temperature, high temperature, starvation, suffocation, pesticide exposure, and food contamination). Then, the body positions of dead bees exposed to each lethal condition were described. This study presents the first attempt to correlate the body position of dead bees to the cause of death.

\section{Materials and methods}

\section{Bee sampling}

The study was conducted in a laboratory maintained at about $26{ }^{\circ} \mathrm{C}$, except when otherwise mentioned. Honey bees (Carniolan hybrid) of foraging age were collected from the lateral combs of three healthy hives (i.e. without any symptoms of diseases) maintained at an apiary in 
Damanhour, Egypt. Bee workers were placed in a Petri dish designed to hold bees (Abou-Shaara, Elbanoby 2017; AbouShaara, Elbanoby 2018). Three Petri dishes, each with five bees, were assigned to each treatment.

\section{Treatments}

The bees were exposed to different stressors at lethal levels up to $100 \%$ death. (1) Low temperature: the bees were placed in a freezer (W. Alaska KS, W. Alaska Co., Gesr El Suez, Cairo, Egypt) maintained at $-20^{\circ} \mathrm{C}$ for 2 h. (2) High temperature: the bees were exposed to a high temperature of about $45^{\circ} \mathrm{C}$ for $2 \mathrm{~h}$ in a sealed box with a $100 \mathrm{~W}$ lamp and a thermometer. (3) Starvation: the bees were placed in a wooden box with some holes for ventilation without food or water for 8 days. (4) Suffocation: the petri dishes were closed tightly and placed in a sealed box without ventilation for 2 days causing the bees to die from lack of oxygen. (5) Insecticide exposure: the bees were sprayed with an aerosol (50\% imiprothrin; El Nasr Co., Giza, Egypt). (6) Food contamination: the bees were fed $50 \%$ sugar syrup $(10 \mathrm{ml})$ contaminated with $0.075 \mathrm{~g}$ malathion (1.5 g Malathion Propelte 5\% DP; Chema Industries, Alexandria, Egypt). Observations were made every $30 \mathrm{~min}$ or on daily basis when rapid or slow death was expected, respectively.

\section{Statistical analysis}

The body position of dead bees was described as presented in Fig. 1. Percentage of bees in each body part position in the cohort of five bees per petri dish was calculated (number of bees with a specific body part position / $5 \times$ 100). Then, percentages of specific positions were averaged and compared within each body part with a Kruskal-Wallis test0.05 (SPSS Inc. 2017, Version 16.0. SPSS Inc., Chicago, USA).

\section{Results and discussion}

The highest percentages of dead bees due to different causes were in body position A, except in case of high temperature (Table 1). Significant differences were found between positions $\mathrm{A}$ and $\mathrm{B}$ in cases of death due to starvation, suffocation, and insecticide exposure. Unfortunately, there are no previous studies on this topic. However, the variations in body position according to death cause can be explained by the potential physiological impacts of death cause on bees. Previous studies showed potential effects
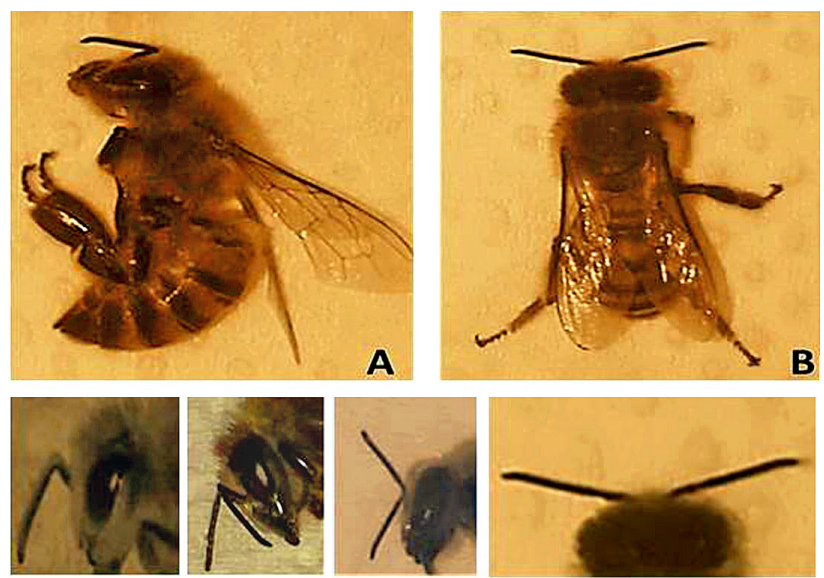

A1

A2
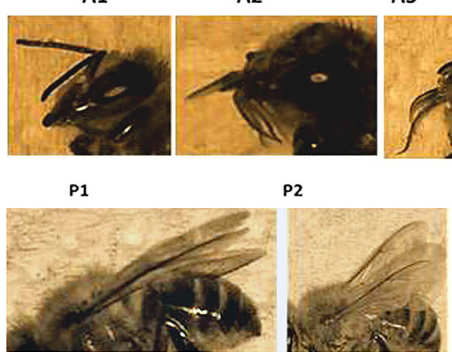

W1

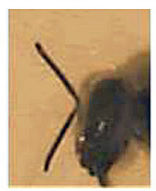

A3

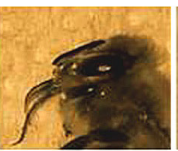

P3

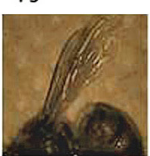

W3

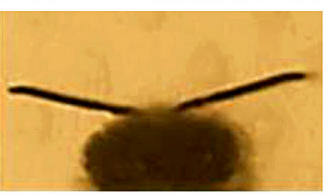

A4

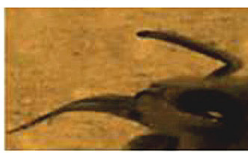

P4

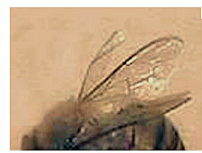

W4

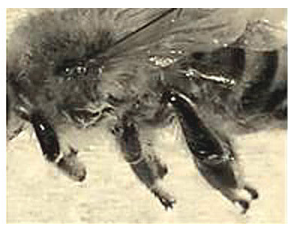

L1

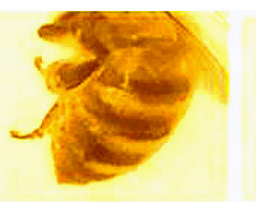

AB1

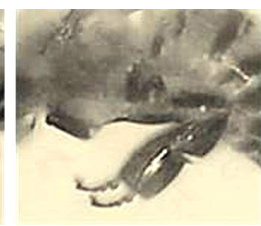

L2

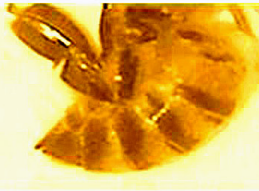

AB2

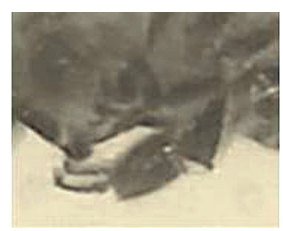

L3

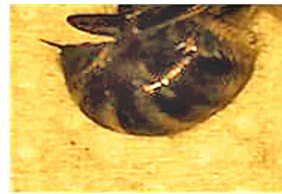

AB3

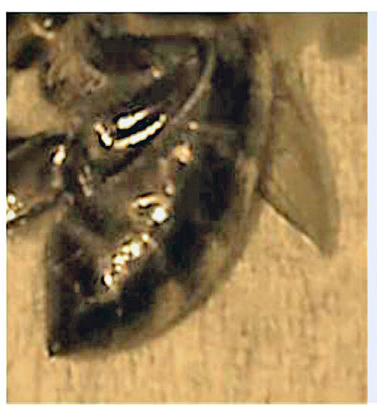

ST1

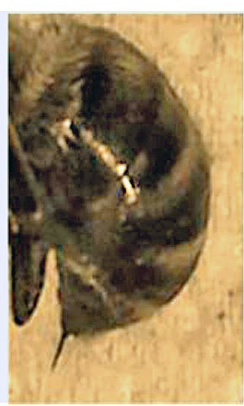

ST2

Fig. 1. General body position: lying on its side (A), or not lying on its side (B). Positions (classes) of antenna: turned towards down (A1), towards down in two directions (A2), one towards down and one towards up (A3), or not towards down (A4). Positions (classes) of proboscis: not protruded (P1), protruded as many parts (P2), protruded as two or three parts (P3), or protruded as one part (P4). Positions (classes) of wings: normal position (W1), angle with thorax (W2), vertical on thorax (W3), or as separated wings in different directions (W4). Positions (classes) of legs (especially hind leg): extended (L1), partially extended (L2), or not extended (L3). Positions (classes) of abdomen: not pressed (AB1), partially pressed (AB2), or completely pressed (AB3). Positions (classes) of stinger: not protruded (ST1), or protruded (ST2). 
Table 1. Means \pm SE of percentages of body positions of dead bees exposed to different stressors. Data were analyzed with the KruskalWallis test

$\begin{array}{lccccccc}\begin{array}{l}\text { Body } \\ \text { position }\end{array} & \text { Low temperature } & \begin{array}{c}\text { High } \\ \text { temperature }\end{array} & \text { Starvation } & \text { Suffocation } & \begin{array}{c}\text { Insecticide } \\ \text { exposure }\end{array} & \begin{array}{c}\text { Food } \\ \text { contamination }\end{array} \\ \text { A } & 73.3 \pm 17.6 & 33.3 \pm 17.6 & 86.6 \pm 13.3 & 86.6 \pm 13.3 & 93.3 \pm 6.6 & 80.0 \pm 20.0 \\ \text { B } & 26.6 \pm 17.6 & 66.6 \pm 17.6 & 13.3 \pm 13.3 & 13.3 \pm 6.6 & 6.6 \pm 6.6 & 20.0 \pm 20.0 \\ \text { Chi-Square } & 2.33 & 1.26 & 4.09 & 4.09 & 4.09 & 2.47 \\ P \text {-value } & 0.12 & 0.26 & 0.04 & 0.04 & 0.04 & 0.116\end{array}$

Table 2. Means \pm SEM of percentages of antenna and proboscis shape of dead bees exposed to different stressors. Data were analyzed with the Kruskal-Wallis test

\begin{tabular}{|c|c|c|c|c|c|c|c|}
\hline Body part & Position & $\begin{array}{c}\text { Low } \\
\text { temperature }\end{array}$ & $\begin{array}{c}\text { High } \\
\text { temperature }\end{array}$ & Starvation & Suffocation & $\begin{array}{c}\text { Insecticide } \\
\text { exposure }\end{array}$ & $\begin{array}{c}\text { Food } \\
\text { contamination }\end{array}$ \\
\hline \multirow[t]{6}{*}{ Antenna } & A1 & $60.0 \pm 23.0$ & $46.6 \pm 6.6$ & 40.0 & $60.0 \pm 20.0$ & $53.3 \pm 13.3$ & $26.6 \pm 17.6$ \\
\hline & $\mathrm{A} 2$ & 0 & $13.3 \pm 6.6$ & $6.6 \pm 6.6$ & $20.0 \pm 11.5$ & $6.6 \pm 6.6$ & $60.0 \pm 11.5$ \\
\hline & A3 & $26.6 \pm 13.3$ & $6.6 \pm 6.6$ & $13.3 \pm 6.6$ & $20.0 \pm 11.5$ & $6.67 \pm 6.6$ & $13.3 \pm 13.3$ \\
\hline & A4 & $13.3 \pm 13.3$ & $33.3 \pm 17.6$ & 40.0 & 0 & $33.3 \pm 13.3$ & 0 \\
\hline & Chi-Square & 6.16 & 5.75 & 9.91 & 6.98 & 7.76 & 6.81 \\
\hline & $P$-value & 0.10 & 0.12 & 0.01 & 0.07 & 0.05 & 0.07 \\
\hline \multirow[t]{6}{*}{ Proboscis } & P1 & $86.6 \pm 6.6$ & $93.3 \pm 6.6$ & $46.6 \pm 6.6$ & $26.6 \pm 13.3$ & $6.6 \pm 6.6$ & $20.0 \pm 20.0$ \\
\hline & P2 & 0 & 0 & $6.6 \pm 6.6$ & 0 & $6.6 \pm 6.6$ & $13.3 \pm 6.6$ \\
\hline & P3 & 0 & 0 & $26.6 \pm 13.3$ & $46.6 \pm 24.0$ & $66.6 \pm 17.6$ & $26.6 \pm 17.6$ \\
\hline & P4 & $13.3 \pm 6.6$ & $6.6 \pm 6.6$ & $20 \pm 11.5$ & $26.6 \pm 26.6$ & $20.0 \pm 11.5$ & $40.0 \pm 11.5$ \\
\hline & Chi-Square & 9.53 & 9.35 & 5.70 & 3.03 & 7.12 & 2.16 \\
\hline & $P$-value & 0.02 & 0.02 & 0.12 & 0.38 & 0.06 & 0.53 \\
\hline
\end{tabular}

Table 3. Means \pm SEM of percentages of wing and leg positions of dead bees exposed to different stressors. Data were analyzed with the Kruskal-Wallis test

\begin{tabular}{|c|c|c|c|c|c|c|c|}
\hline Body part & Position & $\begin{array}{c}\text { Low } \\
\text { temperature }\end{array}$ & $\begin{array}{c}\text { High } \\
\text { temperature }\end{array}$ & Starvation & Suffocation & $\begin{array}{c}\text { Insecticide } \\
\text { exposure }\end{array}$ & $\begin{array}{c}\text { Food } \\
\text { contamination }\end{array}$ \\
\hline \multirow[t]{6}{*}{ Wing } & W1 & $26.6 \pm 17.6$ & $13.3 \pm 6.6$ & 20.0 & $13.3 \pm 13.3$ & $26.6 \pm 6.6$ & 40.0 \\
\hline & W2 & $33.3 \pm 17.6$ & $20.0 \pm 11.5$ & $40 \pm 11.5$ & $46.6 \pm 17.6$ & $13.3 \pm 13.3$ & $6.6 \pm 6.6$ \\
\hline & W3 & 0 & 0 & 0 & $26.6 \pm 26.6$ & $46.6 \pm 17.6$ & 0 \\
\hline & W4 & $40.0 \pm 11.5$ & $66.6 \pm 17.6$ & $40 \pm 11.5$ & $13.3 \pm 6.6$ & $13.3 \pm 13.3$ & $53.3 \pm 6.6$ \\
\hline & Chi-Square & 4.58 & 8.02 & 8.37 & 2.77 & 3.30 & 9.96 \\
\hline & $P$-value & 0.20 & 0.04 & 0.03 & 0.42 & 0.34 & 0.01 \\
\hline \multirow[t]{5}{*}{ Leg } & L1 & $40.0 \pm 11.5$ & $40.0 \pm 30.5$ & $26.6 \pm 6.6$ & $40.0 \pm 11.5$ & $33.3 \pm 17.6$ & $26.6 \pm 13.3$ \\
\hline & $\mathrm{L} 2$ & $33.3 \pm 24$ & $40.0 \pm 23.0$ & $26.6 \pm 17.6$ & 0 & $26.6 \pm 13.3$ & $53.3 \pm 6.6$ \\
\hline & L3 & $26.6 \pm 13.3$ & $20.0 \pm 20.0$ & $46.6 \pm 13.3$ & $60.0 \pm 20.0$ & $40.0 \pm 11.5$ & $20.0 \pm 20.0$ \\
\hline & Chi-Square & 0.44 & 0.65 & 1.53 & 6.00 & 0.51 & 2.66 \\
\hline & $P$-value & 0.80 & 0.72 & 0.46 & 0.05 & 0.77 & 0.26 \\
\hline
\end{tabular}

of pesticides on bee physiology and behavior including learning ability (Moffett and Morton 1975; Herbert et al. 2014; Balbuena et al. 2015; Abou-Shaara and Abuzeid 2018). Perhaps the mode of action of each cause has a role in forming the specific body position of dead bees. Bees exposed to insecticide died quickly, slower for exposure to high or low temperature, followed by suffocation, and finally starvation. These variations in survival times are supported by previous studies on survival ability of bees exposed to different lethal factors (e.g. Atmowidjojo et al. 1997; Remolina et al. 2007; Abou-Shaara et al. 2012; AbouShaara 2017). Such variations could affect the body position of dead bees.

Significant differences were found in the four positions of antenna for all death causes except low and high temperature (Table 2). Position A1 was the dominant position in all death causes except food contamination. Significant differences were found between the four positions of 
Table 4. Means \pm SEM of percentages of abdomen and stinger positions of dead bees exposed to different stressors. Data were analyzed with the Kruskal-Wallis test

\begin{tabular}{|c|c|c|c|c|c|c|c|}
\hline Body part & Position & $\begin{array}{c}\text { Low } \\
\text { temperature }\end{array}$ & $\begin{array}{c}\text { High } \\
\text { temperature }\end{array}$ & Starvation & Suffocation & $\begin{array}{c}\text { Insecticide } \\
\text { exposure }\end{array}$ & $\begin{array}{c}\text { Food } \\
\text { contamination }\end{array}$ \\
\hline \multirow[t]{5}{*}{ Abdomen } & B1 & 0 & $66.6 \pm 17.6$ & 0 & $13.3 \pm 6.6$ & $26.6 \pm 17.6$ & $20.0 \pm 11.5$ \\
\hline & $\mathrm{AB} 2$ & $93.3 \pm 6.6$ & $33.3 \pm 17.6$ & $33.3 \pm 17.6$ & $13.3 \pm 13.3$ & $33.3 \pm 24$ & $60.0 \pm 11.5$ \\
\hline & AB3 & $6.6 \pm 6.6$ & 0 & $66.6 \pm 17.6$ & $73.3 \pm 26.6$ & $40 \pm 11.5$ & $20.0 \pm 11.5$ \\
\hline & Chi-Square & 6.78 & 5.21 & 5.21 & 3.55 & 0.49 & 4.49 \\
\hline & $\mathrm{P}$-value & 0.03 & 0.07 & 0.07 & 0.16 & 0.78 & 0.10 \\
\hline \multirow[t]{4}{*}{ Stinger } & ST1 & 100.0 & $80.0 \pm 20.0$ & $66.6 \pm 24.0$ & $80.0 \pm 20.0$ & $80.0 \pm 11.5$ & 100.0 \\
\hline & ST2 & 0 & $20.0 \pm 20.0$ & $33.3 \pm 24.0$ & $20.0 \pm 20.0$ & $20.0 \pm 11.5$ & 0 \\
\hline & Chi-Square & 5.00 & 2.47 & 1.26 & 2.47 & 3.85 & 5.00 \\
\hline & $P$-value & 0.02 & 0.11 & 0.26 & 0.11 & 0.05 & 0.02 \\
\hline
\end{tabular}

proboscis for all death causes except starvation, suffocation, and food contamination. The highest percentages of dead bees were in position P1 for low and high temperature and starvation while position P3 and P4 for the other causes of death (Table 2). The potential physiological impacts of death causes on bees can be responsible for the variations of positions of antenna and proboscis.

Three death causes (high temperature, starvation, and food contamination) showed significant differences in the four positions of wings (Table 3). Positions of wings varied according to the death cause, and the highest percentages were in position $\mathrm{W} 4$ in cases of low and high temperature, starvation, and food contamination, while W2 was more common in the case of suffocation and W3 in the case of insecticide exposure. Legs showed lack of significant differences between the three positions for all death causes except suffocation (Table 3). Most bees that died due to suffocation had leg position L3. This specific leg position was dominant when bees were intensively treated with some materials causing bee death as a result of suffocation (Abou-Shaara et al. 2016). It is clear that positions of wings are more specific than legs according to cause of death.

The abdomens of dead bees tended to be in position $\mathrm{AB} 1$ in the case of high temperature, in position $\mathrm{AB} 2$ in cases of low temperature and food contamination, and in position AB3 for the other death causes (Table 4). Significant differences were found in positions of abdomen only in cases of low and high temperature, and starvation. Exposure of bees to some lethal factors like high temperature can cause loss of body water (Atmowidjojo et al. 1997; Al-Qarni 2006; Abou-Shaara 2015b), and hence may cause changes in the shape of abdomen of dead bees. The stinger tended to be in position ST1 for all death causes (Table 4). It is clear that the positions of abdomen are more specific to death cause than stinger positions. This can be explained by the few positions of stinger compared to abdomen.

The dead bees can be described according to the death cause based on the percentages of each body part position using the following description. Low temperature - body position: A; antenna: A1; proboscis: $\mathrm{P} 1$; wings: W2; legs:
L1; abdomen: AB2; stinger: ST1. High temperature - body position: B; antenna: A1; proboscis: P1; wings: W4; legs: L1or L2; abdomen: AB1; stinger: ST1. Starvation - body position: A; antenna: A1 or A4; proboscis: P1; wings: W2 or W4; legs: L3; abdomen: AB3; stinger: ST1. Suffocation - body position: A; antenna: A1; proboscis: P3; wings: W2; legs: L3; abdomen: AB3; stinger: ST1. Insecticide exposure - body position: A; antenna: A1; proboscis: P3; wings: W3; legs: L3; abdomen: AB3; stinger: ST1. Food contamination - body position: A; antenna: A2; proboscis: P4; wings: W4; legs: L2; abdomen: AB2; stinger: ST1.

\section{Conclusions}

This study presents baseline observations on relationships between the body position of dead bees and stress factors, which might be used to predict the cause of death of honey bee workers. Additional studies will need to be conducted to gather data to strengthen the patterns observed in this study. Further investigations using different bee castes (queens, drones, and workers), quantifiable measurements (e.g., angles between body parts), and additional causes of death (such as heavy parasite infection, contaminated nectar or pollens, or age) are advised. These data may be used to develop a predictive algorithm or computer program to determine cause of death based on the body position of dead bees.

\section{References}

Abou-Shaara H.F. 2015a. Pollen sources for honey bee colonies at land with desert nature during dearth period. Agron. Res. Mold. 48: 73-80.

Abou-Shaara H.F. 2015b. Thermal tolerance characteristics of two honey bee races. J. Agric. Urban Entomol. 31: 1-8.

Abou-Shaara H.F. 2017. Effects of various sugar feeding choices on survival and tolerance of honey bee workers to low temperatures. J. Entomol. Acarol. Res. 49: 6-12.

Abou-Shaara H.F., Abuzeid M.A. 2018. Effects of two herbicides on healthy and Nosema infected honey bee workers. Arthropods 7: 31-41. 
Abou-Shaara H.F., Elbanoby M.I. 2017. Using new cage type for keeping virgin honey bee queens with investigating impacts of feeding type and number of attendant workers. Egypt. Acad. J. Biol. Sci. 10: 81-87.

Abou-Shaara H.F., Elbanoby M.I. 2018. Factors impacting survival of mature honey bee drones kept in small laboratory cages. Environ. Exp. Biol. 16: 39-44.

Abou-Shaara H.F., Al-Ghamdi A.A., Mohamed A.A. 2012. Tolerance of two honey bee races to various temperature and relative humidity gradients. Environ. Exp. Biol. 10: 133-138.

Abou-Shaara H.F., Al-Ghamdi A.A., Mohamed A.A. 2013. Honey bee colonies performance enhance by newly modified beehives. J. Apicult. Sci. 57: 45-57.

Abou-Shaara H. F., Staron M., Cermáková T. 2016. Impacts of intensive dusting or spraying with Varroa control materials on honey bee workers and drones. J. Apicult. 31: 113-119.

Al-Ghamdi A.A., Alsharhi M.M., Abou-Shaara H.F. 2016. Current status of beekeeping in the Arabian countries and urgent needs for its development inferred from a socio-economic analysis. Asian J. Agric. Res. 10: 87-98.

Al-Qarni A.S. 2006. Tolerance of summer temperature in imported and indigenous honeybee Apis mellifera L. races in central Saudi Arabia. Saudi J. Biol. Sci. 13: 123-127.

Atmowidjojo A.H., Wheeler D.E., Erickson E.H., Cohen A.C. 1997. Temperature tolerance and water balance in feral and domestic honey bees, Apis mellifera L. Compar. Biochem. Physiol. 118A: 1399-1403.

Balbuena M.S., Tison L., Hahn M.-L., Greggers U., Menzel R., Farina W.M. 2015. Effects of sublethal doses of glyphosate on honeybee navigation. J. Exp. Biol. 218: 2799-2805.

Barker R., Lehner Y., Kunzmann M.R. 1980. Pesticides and honey bees: Nectar and pollen contamination in alfalfa treated with dimethoate. Arch. Environ. Contam. Toxicol. 9: 125-133.

Brodschneider R., Moosbeckhofer R., Crailsheim K. 2010. Surveys as a tool to record winter losses of honey bee colonies: a two year case study in Austria and South Tyrol. J. Apicult. Res. 49: 23-30.

Carreck N. 2014. Electromagnetic radiation and bees, again. Bee World 91: 101-102.

Dively G.P., Kamel A. 2012. Insecticide residues in pollen and nectar of a cucurbit crop and their potential exposure to pollinators. J. Agric. Food Chem. 60: 4449-4456.

Genersch E., Ohe W.V.D., Kaatz H., Schroeder A., Otten C., Buchler R., Berg S., Ritter W., Muhlen W., Gisder S., Meixner M., Liebig G., Rosenkranz P. 2010. The German bee monitoring project: a long term study to understand periodically high winter losses of honey bee colonies. Apidologie 41: 332-352.

Herbert L.T., Vázquez D.E., Arenas A., Farina W.M. 2014. Effects of field-realistic doses of glyphosate on honeybee appetitive behavior. J. Exp. Biol. 217: 3457-3464.

Johnson R.M. 2015. Honey bee toxicology. Annu. Rev. Entomol. 60: 415-434.

Maini S., Medrzycki P., Porrini C. 2010. The puzzle of honey bee losses: a brief review. Bull. Insectol. 63: 153-160.

Moffett J.O., Morton H.L. 1975. How herbicides affect honey bees. Am. Bee J. 115: 178-179.

Morse R.A., Calderone N.W., 2000. The value of honey bees as pollinators of U.S. crops in 2000. Bee Cult. 128: 2-15.

Nguyen B.K., Mignon J., Laget D., De Graaf D., Jacobs F.J., van Engelsdorp D., Brostaux Y., Saegerman C., Haubruge E., 2010. Honey bee colony losses in Belgium during the 2008-9 winter. J. Apicult. Res. 49: 337-339.

Oldroyd B.P. 2007. What's killing American honey bees? PLoS Biol. 5: e168.

Qaiser T., Ali M., Taj S., Akmal N. 2013. Impact assessment of beekeeping in sustainable rural livelihood. J. Soc. Sci. 2: 82-90.

Remolina S.C., Hafez D.M., Robinson G.E., Hughes K.A. 2007. Senescence in the worker honey bee Apis mellifera. J. Insect Physiol. 53: 1027-1033.

Spleen A.M., Lengerich E.J., Rennich K., Caron D., Rose R., Pettis J.S., Henson M., Wilkes J.T., Wilson M., Stitzinger J., Lee K., Andree M., Snyder R., van Engelsdorp D. 2013. A national survey of managed honey bee 2011-12 winter colony losses in the United States: results from the bee informed partnership. J. Apicult. Res. 52: 44-53.

vanEngelsdorp D., Hayes J., Underwood R.M., Pettis J. 2008. A survey of honey bee colony losses in the U.S., Fall 2007 to Spring 2008. PLoS One 3: e4071.

Zhang W.J. 2018. Global pesticide use: Profile, trend, cost / benefit and more. Proc. Int. Acad. Ecol. Environ. Sci. 8: 1-27. 